\title{
COMMENTS
}

\section{APPOINTMENT OF GUARDIANS FOR THE MENTALLY INCOMPETENT}

\begin{abstract}
D ue ro the policy of protecting mentally disabled persons against their own weaknesses and the unscrupulousness of others, such individuals comprise one of the classes of persons upon whom involuntary guardianships may be imposed. ${ }^{1}$ An adjudication of mental incompetency divests the incompetent of control over his property, deprives him of many of the civil rights he formerly enjoyed, ${ }^{2}$ and results in the appointment of a guardian to manage his affairs. ${ }^{3}$ This comment will examine and evaluate the various substantive tests and evidentiary requirements which are employed in guardianship proceedings.
\end{abstract}

\section{Criteria for Determining Mental. Incompetency}

Mental disability may be significant in various legal proceedings, ${ }^{4}$ and the rules for establishing the requisite type and degree tend to depend on the purpose for which mental illness or deficiency is

${ }^{2}$ Statutes in every state so provide. Other statutory classes of persons subject to incompetency adjudication and imposition of guardianship include alcoholics, drug addicts, spendthrifts, and persons disabled by senility or "old age." See LiND.raN \& Mfointyre, The Mfentally Disabled and the Law 220, 230-34, 239-51 (1961) [hereinafter cited as LINDMAN \& MICINTYRE].

About one-fourth of the jurisdictions provide for an incompetency adjudication of persons who are unfit to care for themselves or their property due to physical disability. See, e.g., Del. Code ANx. tit. 12, \$ 3914 (Supp. 1962); D.C. CODE AN. \$ 21-501 (1961); FLA. STAT. \$ 394.22(1) (1960); S.D. CODE $\$ 35.1802$ (Supp. 1960). But see Schafer v. Haller, 108 Ohio St. 322, 140 N.E. 517 (1923) (statute making physical infirmity a basis for incompetency adjudication violated the Ohio constitution); Note, 45 Iow' L. Rev. 360,367 (1960).

"Statutes in most states limit the rights of incompetent persons to execute contracts and conveyances, to make wills, and to institute legal proceedings. Incompetency may also result in curtailment of the right to practice certain professions, to operate notor vehicles, to vote, to hold public office and to serve on a jury. Sec LrNoma. \& MCINTYRE 263.69, 275-97.

"In some states the term "committee," "conservator," or "curator" is used instead of "guardian." The court may generally appoint a guardian for the person or the estate of the incompetent, or both. In most states separate guardians may be appointed for the incompetent's person and estate. See LiNdiAN \& McINTYRe 239-51.

4 Mezer \& Rheingold, Mental Capacity and Incompetency: A Psycholegal Problem, 118 Au. J. Psrchiatry 827 (1962), lists thirty-one legal areas in which determination of mental incompetency may be important. 
to be proved..$^{5}$ Although the insanity which results in avoidance of criminal liability or invalidation of a contract is not necessarily equivalent to the "insanity," "idiocy," "Iunacy," "imbecility" or "unsoundness of mind" which will justify guardianship, ${ }^{6}$ until recently statutes generally did not define such terms for guardianship purposes. Hence the courts in incompetency proceedings have developed a body of definitions relating to each category.

The earliest basis for guardianship of an adult was his insanity. Early common law courts divided insane persons into two categories, "idiots" (or "natural fools"), without understanding from birth," and "lunatics," once of sound mind but having subsequently lost their reason. ${ }^{8}$ The more recent tendency has been to blur this distinction between idiocy and lunacy while broadening the meaning of insanity to the extent that the latter term now comprehensively includes all serious disabilities of the mind. ${ }^{\circ}$ The terms insanity, idiocy and lunacy are significant today in incompetency proceedings only insofar as they indicate that one is unable to manage the ordinary affairs of life or to transact ordinary business. ${ }^{10}$ Imbecility, traditionally considered to be weakness of mind and to imply a lesser degree of disability than did insanity, ${ }^{11}$ also indicates, in modern incompetency proceedings, that the individual lacks the capacity to deal with the ordinary affairs of life. ${ }^{12}$ And unsoundness

\footnotetext{
5nyder v. Snyder, 142 Ill. 60, 67, 31 N.E. 303, 306 (1892). Sce Estate of Haywood v. Haywood, 109 Cal. App. 2d 388, 240 P.2d 1028 (Dist. Ct. App. 1952).

"These are the traditional designations of mental conditions denoting in. competency. At present insanity is a statutory basis for incompetency adjuclication in twenty states, idiocy in twelve, and lunacy in eight. Imbecility and unsoundness of mind each justify guardianship in ten jurisdictions. Sce LiNDMAN \& MIclNTYRE $230-34$

- See In the Matter of Beaumont, 1 Whart. 52 (Pa. 1836).

${ }^{s}$ DeNardo v. DeNatdo, 293 N.Y. 550, 59 N.E.2d 241 (1944); In the Matter of Clark, 57 App. Div. 5, 67 N.Y. Supp. 631 (1900). Definitions of and distinctions between icliocy and Iunacy apparently were first codified in the statute de Praerogative regis, I7 Edw: 2, c. 9 (cir. 125j-1290). I Holdsworth, A History of Exclisn Law 473 (7th ed. 1956).

${ }^{\circ}$ Dribin v. Staperior Court, 37 Cal. 2d 345, 231 P.2d 809 (1951); Beattic r. Bowcr, 290 .Iich. 517,287 N.TV. 900 (1999).

10 See, e.g., In the Matter of Crouse, 140 Mo. App. 54j, 120 S.Tl. 666 (1999); Lewis v. Lewis, 199 S.C. 490, 20 S.E.2d 107 (1942); In re Wetmore's Guardianship, 6 Wash. 271, 33 Pac. 615 (1893). As to what constitutes such inability, sec infra note 17.

${ }^{11}$ Barnes v. Watcrman, 54 Misc. 392, 104 N.Y. Supp. 685 (Sup. Ct. 1907), aff'd mem., 129 App. Div. 929, 104 … Supp. 1118 (1908); Messenger $v$ Bliss, 35 Ohio St. 587 $(1880)$.

12 In re Appointment of a Guardian for Emswiler, 11 Ohio Dec. 10, 8 Ohio N.P. 132 (P. Ct, 1900).
} 
of mind, which once implied total deprivation of sense, ${ }^{13}$ is generally considered to be synonymous with insanity ${ }^{14}$ and, therefore, to signify the degree of mental infirmity which renders the alleged incompetent incapable of caring for his property or of transacting ordinary business. ${ }^{15}$

It is thus apparent that courts generally consider such terms as insanity, idiocy, lunacy, imbecility and unsoundness of mind to be nearly interchangeable for purposes of incompetency adjudication. Any test for mental incompetency tends to be framed not as a type or cause of mental disability, but in terms of its practical effects upon the alleged incompetent's conduct of the ordinary affairs of life. ${ }^{16}$ Yet the tests generally indicate no measuring standard to which his ability to manage ordinary affairs must conform..$^{17}$ Ap-

${ }^{23}$ Riggs v. American Tract Soc'y, 84 N.Y. 330 (1881).

14 Sabin v. Commonwealth, 233 Ky. 636; 26 S.W.2d 506 (1930); Fendler v. Roy, 331 Mo. 1083, 58 S.W.2d 459 (1932); In the Matter of Application of Jordan, 170 Misc. 734, 10 N.Y.S.2d 9I1 (Sup. Ct. 1939); In re Nitey's Estate, 175 Okla. 389, 53 P.2d 215 (1935); Cundell v. Haswell, 23. R.I. 508, 51 Atl. 426 (1902). Contra, In re Guadianship of Kappel, 242 Iowa 1021, 47 N.W.2d 825 (1951).

${ }^{25}$ Fendler v. Roy, supra note 14; In the Matter of Guardianslip of Nelson, 12 Wash.2d 382, 121 P.2d 968 (1942); In re Streiff, 119 Wis. 566, 97 N.W. 189 (1903).

${ }^{10}$ Many statutes and courts no longer employ the traditional terms and simply designate as incompetent any person who from any cause is mentally incapable of taking care of himself or his property. See, e.g., ArIz. REv. STAT. ANN. $\$ 14-861$ (1956); Del. Code ANn. tit. 12, $\$ 3914$ (Supp. 1962); Ore. Rev. Stat $\$ 126.006(3)$ (Supp. 1961); UTAH Code ANN. $\$ 75-13-19$ (1953); In the Matter of Estate of Estee, 32 11l. App. 2d 149, 177 N.E.2d 15 (1961); Sabin v. Commonwealth, 233 Ky. 636, 26 S.W.2d 506 (1930); In re Blaine's Guardianship, 195 Okla. 205, 156 P.2d 583 (1945); Wingert Case, 163 Pa. Super. 616, 63 A.2d 441 (1949).

It has been suggested that such terms as insanity, idiocy, lunacy and imbecility are objectionable as tending to stigmatize the incompetent. Note, 45 IowA L. REv. 360,368 (1960). Since in modern incompetency proceedings it is practical managerial ineptness which generally is determinative, it would seem that these traditional terms could be eliminated from the statutes and replaced by a general term such as "mentally incompetent."

${ }^{17}$ Most courts state that the alleged incompetent is not required to manage his property "judiciously." See, e.g., In re Johnson's Estate, 286 Mich. 213, 281 N.W. 597 (1938); In re Delany, 226 S.W.2d 366 (Mo. Ct. App. 1950); In re Northcutt, 81 Ore. 646, 148 Pac. 1133 (1915); Leatherman v. Leatherman, 82 W. Va. 748, 97 S.E. 294 (1918). However, it has been stated occasionally that he may be held to a standard of ordinary reasonable care and prudence in managing his affairs. Muller v. De Vries, 193 Iowa 1337, 188 N.W. 885 (1922). Statutes and decisions which require that the alleged incompetent act "with discretion" or manage his property "properly" seem to imply some comparative community standard like that of the reasonable man. See, e.g., Lewis v. Lewis, 199 S.C. 490,20 S.E.2d 107 (1942); N.M. Star. ANN. \$ 32-2-1 (Supp. 1953). Other standards occasionally advanced include ability to manage property "in a rational manner," Olson v. Olson, 242 Iowa 192, 46 N.W.2d 1 (1951), or "intelligently," In re Johnson's Estate, supra. One court has stated that the alleged incompetent must appear to be normal "in the usual acceptation of that term." In the Matter of Guardianship of Coburn, 11 Cal. App. 604, 606, 
párently'no "set rule can 'be enunciated that will function in all cases as' a safe criterion of mental incompetency. ${ }^{18}$ Since the difference between competency and incompetency is merely one of degree, ${ }^{19} ;$ any. set standard becomes elastic and relative when applied to various factual contexts, and determination of competency or incompetency depends almost totally on the particular facts of each case $^{20}+\ldots+\cdots ;$

\section{EVIDENTIARY REQUUREMENTS}

The states are also in 'substantial agreement as to the kind of evidence which will support:a finding of mental incompetency under some general test. Although tests for mental incompetency are sometimes phrased rather subjectively, ${ }^{21}$ the only available indicia of a person's mental condition are external; consequently, an inquiry into mental competency is an inquiry into overt behavior. ${ }^{22}$; Generally the existence and extent of mental disability can best' be 'determined from direct evidence of the alleged in-

105 Pac. 924, 925 (Dist. Ct. App: 1909), aff'd 165 Cal. 202, 131 Pac. 352 (1913). But see Gleveland's Appeal, 72 Conn. 340, 44 Atl. 476 (1899).

limprovidence, the usual basis 'for incompetency adjudication as to spendthrifts, does not of itself indicate mental incompetency, though evidence of it is admissible as tending to indicate some mental disability. Where, however, incompetency statutes are construed tó 'operate prospectively in order to protect a' mentally disabled person from his own future weakness, no specific instances of past dissipation by or victimization of the alleged incompetent need be shown to justify guardianship. Arthur's Cáse, 136 Pà. 'Super. 261, 7 A.2d 55 (1939). "A disposition of mind ... which might lead to the wasting of an estate is sufficient to justify the appointment." Guardianship of Gordon, 56 Cal. App. 2d 523, 528-29, 132 P.2d 824, 827 (Dist. Ct. App. 1943) (Emphasis added.) Contra, Lang v. Lang, 157 Iowa 300, 135 N.W. 604 (1912). See note 59 infrà."

${ }^{18}$ Keiser v'. Keiser, II3 Neb. 645, 204 N.W. 394 (I925); In' re Guardianship of Wilson, 23 Ohio App. 390, 155 N.E. 654 (1926).

${ }^{18}$ Lewis v. Iewis, 199 S.C. 490,20 S.E.2d 107 (1942). "The mind grades up from zero to the intellectual boiling point' so gradually that dogmatic tests are of littla value." Slaughter v. Heath, 127 Ga. 747, 751, 57 S.E. 69, 71 (1907).

${ }^{20}$ Interdiction of Grevening, I64 La. 1026, 115 So. 133 (1927).

${ }^{21}$ Some courts stress the alleged incompetent's ability to understand and appreciate the nature and effect of his actions: See, e.g., Leatherman v. Leatherman, $82 \mathrm{~W}$. Va. 748, 97 S.E. 294 (1918). Such an approach may be misleading as it tends to focus exclusively on the cognitive, intellectual processes and to overlook the effects of emotional disturbance on the individual's conduct. If, for instance, "understanding" is the sole criterion for mental competency, the manic-depressive must be held competent, Lovell v: Keller, 146 Misc. 100, 261 N.Y. Supp. 557 (N.X. Cíty Ct. 1933), since the psychosis from which he suffers affects motivation rather than the ability to understand. "Faber'v. Sweet Style Mfg. Corp., 40 Misc. 2d 212, 242 N.Y.S.2d 763, 767 '(Sup. Ct. I963)."

22 See Green, Judicial Tests of Mental Incompetency, 6 Mo. L. Rev. 141, 144-46 (1941): 'Leifer, The Competence of the Psychiatrist to Assist in the Determination of Incompetency: $A$ 'Sceptical Inquiry into the Courtroom Functions of Psychiatrists, 14 SYRACUSE L. REv.'564, 567, 572 (1963). 
competent's words, acts, appearance and physical condition, ${ }^{23}$ and from lay and medical opinion either based on close association with and observation of him, ${ }^{24}$ or, as to the expert, ${ }^{25}$ given in response to hypothetical questions. ${ }^{26}$ Statutes in several jurisdictions require oral testimony or a sworn certificate from at least one qualified medical witness. ${ }^{27}$ Absent any statutory prescription, courts differ as to the relative weight to be accorded lay and medical testimony; but in some jurisdictions there appears to be increasing deference to medical opinion. ${ }^{28}$ Moreover, statutes in several states provide for determination of mental incompetency by medical commissions alone. ${ }^{20}$ In most states, however, whatever the medical expert's opinion, the trier of fact, whether judge or jury, determines competency or incompetency. The alleged incompetent has no federal constitutional right to a jury determination of his mental condition, ${ }^{30}$ and although statutes or common law decisions in a substantial minority of jurisdictions confer such a right, ${ }^{31}$ the usual procedure is to place the task of evidentiary evaluation, and thus any determina-

${ }^{23}$ Fiala v. Tomek, I64 Neb. 20, 81 N.W.2d 691 (1957); In re Guardianship of Smith, 26 Ohio N.P. (n.s.) 533 (1927); In re Meyers, 410 Pa. 455, 189 A.2d 852 (1963); In re Martin's Estate, 57 Lanc. Rev. 191 (Pa. C.P. 1961).

${ }^{24}$ Dean v. United States, 150 F. Supp. 541 (W.D. Okla. 1957); Anthony v. Anthony, 20 11l. 2d 584, 170 N.E.2d 603 (1960).

${ }^{25}$ Whether the witness qualifies as an expert is a matter of law to be determined by the trial judge in his discretion. See MCCORMICK, EvidENCE $\S 13$ (1954); 20 AM. JuR. Evidence $\$ 851$ (1939).

20 See McCormick, Evidence $\S 14$ (1954); 20 AM. Jur. Evidence $\S 850$ (1939). While hypothetical questions are widely employed in proceedings to determine a person's mental condition, it has been stated that they yield "evidence of the weakest and most unsatisfactory character." In the Matter of Estate of Mitchell, 41 Wash. 2d 326, 346, 249 P.2d 385, 397 (1952).

${ }^{27}$ See, e.g., Ark. Stat. Ann. \$ 57-615 (b) (Supp. 1963); MD. Ann. Code art. 16, § 135 (Supp. 1963); Mass. Gen. Laws ch. 201, $\$ 6$ (Supp. 1962).

${ }_{28}$ See, e.g., In the Matter of Guardianship of Waite, 33 Cal. App. 2d 315, 91 P.2d 617 (Dist. Ct. App. 1939); In the Matter of Guardian for Lugo, 10 Misc. 2d 576, 172 N.Y.S.2d 104 (Ct. CI. 1958).

20 Colo. Rev. Srat. AnN. \$§ 71-1-2, -6 (1953); Young v. Brofman, 139 Colo. 296, 338 P.2d 286 (1959) (determination of medical commission is "adjudication" of incompetency); GA. Code ANN. § 49-604 (Supp. 1963).

${ }^{30}$ See Simon v. Craft, 182 U.S. 427 (1901) (due process of law does not require jury trial in insanity proceedings); Ward v. Booth, 197 F.2d 963 (9th Cir. 1952). But see Hager v. Pacific Mut. Life Ins. Co., 43 F. Supp. 22, 26 (E.D. Ky. 1942) (dictum): "I do not believe that under our Federal and State Constitutions a person can be declared incompetent and have his property taken out of his Hand ... without the intervention ... and the verdict of a jury."

${ }^{31}$ Several courts hold that there was at common law in incompetency proceedings a right to trial by jury which is preserved and extended by the state's constitutional guarantee of jury trial. Other jurisdictions deny the existence of a common law right to jury trial in such proceedings, but hold that such a right obtained by statute prior to the adoption of the state constitution and was therefore incorporated in the 
tion of mental incompetency and the need for guardianship, in the hands of a lower court judge. ${ }^{32}$

Illustrative of several problems which may arise under this procedure is the recent case of In the Matter of Guardianship of Tyrrell. ${ }^{33}$ Immediately prior to the hearing, Tyrrell, the alleged incompetent, was examined for fifteen minutes by two physicians selected by the applicant for the guardianship. ${ }^{34}$ Their opinions, based partly on the brief examination and partly on what they had heard, were that a guardianship was needed because the alleged incompetent was "subject to undue influence." 35 The applicant's other evidence tended to show that during the preceding year the alleged incompetent had spent several thousand dollars for which he had not received proper service or value. ${ }^{\mathbf{3 6}}$

Testimonial evidence to support Tyrrell's competency was offered by his personal physician, the supervisor of the rest home where he had resided for two years, four old friends with whom he had lately conversed on numerous occasions, and several local businessmen with whom he had recently dealt. ${ }^{37}$ His recent business transactions had included purchase of a diamond ring for less than the normal selling price and of a modest grave monument for himself and his deceased wife; the making of funeral arrangements for himself for $\$ 1,000$; and a contract for lifetime care in a rest home for $\$ 2,500 . .^{88}$ He also held a hospitalization insurance policy. ${ }^{30}$ He had apparently provided amply for himself to the end of his days and would not have had to depend for sustenance on the assets which he had allegedly dissipated. The probate court nonetheless found that a mental disability existed which prevented Tyrrell from dealing at arm's length, declared him mentally incompetent, and directed that a

constitutional guarantee. See Lindman \& Mcintyre 224, 239-51; Annot., 33 A.L.R.2d 1145 (1954).

${ }^{32}$ E.g., IDAho Code ANN. $\$ 15-1815$ (1948); ME. Rev. STAT. ANN. ch. I58, $\$ 4$ (Supp. 1963). See generally Lindian \& McINTYRE 239-51.

${ }^{33} 92$ Ohio L. Abs. 253 (P. Ct.), aff'd (Ohio App. 1962), appeal dismissed mem. for lack of debatable constitutional question, 174 Ohio St. 552, 190 N.E.2d 687 (I963).

3492 Ohio L. Abs. at 254.

35 Ibid.

${ }^{30} 92$ Ohio L. Abs. at 255 . The opinion does not state the evidence upon which the court based its conclusion.

${ }^{37}$ Brief for Appellant in the Supreme Court of Ohio, p. 5. In addition the probate judge stated that throughout the proceedings the alleged incompetent "followed the testimony of the witnesses quite carefully." 92 Ohio L. Abs. at 254.

${ }^{38}$ Brief for Appellant in the Supreme Court of Ohio, p. 14.

so $\mathrm{Ibid}$. 
guardian be appointed for his person and estate. ${ }^{40}$ The finding and order were affirmed on appeal, ${ }^{41}$ the appellate court being unable to say that the probate court's decision was not "in the best interest of the ward." 42

\section{The Inadequacy of Safeguards Under Present Law}

A case such as Tyrrell seems to indicate an inherent weakness in the present machinery of incompetency proceedings in many jurisdictions. ${ }^{43}$ The task of a probate judge entrusted with the conduct of such proceedings is formidable. He must pierce the atmosphere of emotional antagonism so often incident to such cases and evaluate the evidence. He must discern the existence and extent of mental disability, a task which may require him to pass judgment as an expert on the alleged incompetent's mental condition. ${ }^{44} \mathrm{He}$ must interpret and apply a standard of incompetency, taking into account such evidence as he deems relevant, and decide in the best interest of the

4092 Ohio L. Abs. at 256.

11 Case No. 142, Court of Appeals of Preble County, Ohio, Oct. 31, 1962.

19 Id. at 8. Even assuming that Tyrrell had dissipated his property, appointing a guardian for him under all the circumstances seems questionable purely on policy grounds. Tyrrell was a childless widower with no dependents who had completely provided for his future, and it is difficult to conceive the harm to him in allowing him to retain control over his remaining assets, if his own welfare is the determinative factor. See In re Johnson's Estate, 286 Mich. 213, 281 N.W. 597 (1938) (showing that an aged person is unwise, lacks judgment, indulges in folly, or squanders his property held not sufficient to warrant guardianship); In the Matter of Guardianship of Valentine, 4 Utah 2d 355, 363, 294 P.2d 696, 702 (1956) ("The right of every individual to handle his own affairs even at the expense of dissipating his fortune is a right jealously guarded and one which will not be taken away except in extreme cases"); In re Guardianship of Mills, 250 Wis. 401, 27 N.W.2d 375 (1947) (courts should be extremely hesitant to interfere with discretion of elderly people, owing no legal duty to support anyone, in utihizing their property according to their own tastes).

13 The substantial similarity in both substantive and procedural incompetency law among many jurisdictions renders it difficult to ascribe the result in Tyrrell to purely local factors. It seems likely that similar cases exist in many other states.

"In Tyrrell the probate judge noted: "that his [Tyrrell's] smile at times is not normal; his eyes do not focus properly at all times; his gait and reflexes are not normal; ... he is not laying his cane aside, but is dropping it," and concluded that "these are indications of the lessening of ... [Tyrrell's] mental capacities." 92 Ohio L. Abs. at 256. Before the Ohio Supreme Court, Tyrrell's counsel challenged these observations as insufficient to support a finding of "mental illness" on the ground that (1) the lack of eye focus was due to a detached retina; (2) the probate judge was hardly able to determine the normalcy of Tyrrell's "gait and reflexes" since he had never observed the alleged incompetent out of his wheel chair; (3) the quality of Tyrrell's smile could have been better gauged had the judge seen him at a distance closer than that from the counsel table to the bench. Brief for Appellant in the Supreme Court of Ohio, pp. 24-25. Tyrrell's counsel also objected to the probate judge's failure to examine personally the alleged incompetent upon the latter's request that he do so. Id. at 24 . 
alleged incompetent whether or not to impose a guardianship. In performing this task he has broad discretionary powers. ${ }^{45} \mathrm{~A}$ determination of mental incompetency, although reviewable on appeal, ${ }^{46}$ is grounded so deeply in discretion that an appellate court may be reluctant to set it aside if a record merely shows sufficient evidence to support the probate court's conclusion. ${ }^{47}$

Since the effects of incompetency adjudication are not unlike those attendant upon certain criminal convictions, ${ }^{48}$ it is suggested that a finding of mental incompetency should at least require that the evidence tending to indicate incompetency be "clear and convincing." ${ }^{40}$ A lesser requirement may not adequately protect the alleged incompetent. Where, as in Tyrrell, determination of mental incompetency is sustained if there is merely "sufficient probative evidence," 50 an appellate court apparently need not consider the proportion and quality of contradictory evidence which the probate

${ }^{15}$ Case No. 142, Court of Appeals of Preble County, Ohio, Oct. 31, 1962, p. 6; OHio Rev. CODE § 2111.02 (Page 1961). Accord, In re Hogan, 135 Me. 249, 194 Atl. 854 (1937); Purdum v. Lilly, 182 Md. 612, 35 A.2d 805 (1944); In re Guardianship of Strom, 205 Minn. 399, 286 N.W. 245 (1939); In re Guardianship of Lyon, 140 Neb. 159, 299 N.W. 322 (1941); In the Matter of Guardianship of Mignerey, 11 Wash. 2d 42, 118 P.2d 440 (1941).

${ }^{48}$ See, e.g., Miller v. Paulson, 185 Iowa 218, 169 N.W. 203 (1918); In the Matter of Estate of Grove, 158 Kan. 444, 148 P.2d 497 (1944); Chase v. Chase, 216 Mass. 394, 103 N.E. 857 (1914); In re Guardianship of Winnett, 112 Okla. 43, 239 Pac. 603 (1925). But cf. In the Matter of Estate of Reed, 198 Cal. 148, 243 Pac. 674 (1926) (lower court's finding of incompetency not reviewable on appeal if evidence is conflicting).

${ }^{17}$ See In the Matter of Guardianship of Sears, 44 Ariz. 408, 38 P.2d 308 (1934); In the Matter of Guardianship of Cowper, 179 Cal. 347, 176 Pac. 676 (1918); In re Kellogg, 196 Mich. 119, 162 N.W. 1032 (1917); In re Guardianship of Wolff, 232 Minn. 144, 44 N.W.2d 465 (1950). Other courts will not disturb a finding of incompetency unless clear abuse of discretion by the trial judge is shown. Arent v. Arent, 239 Iowa 737, 32 N.W.2d 660 (1948); In re Knott's Guardianship, 71 S.D. 53, 21 N.W.2d 59 (1945).

${ }^{48}$ The adjudicated incompetent, like the convicted criminal, is deprived of control over his property. He may be socially stigmatized, especially where he is decreed an idiot, lunatic, or imbecile. Moreover, while direct commitment to a mental institution may not follow incompetency adjudication, in some states the incompetent's guardian may apply for "voluntary admission" of his ward to a mental hospital without following the normal statutory procedures. Where this is possible the incompetent may not be adequately protected against involuntary incarceration. Scc LINDMAN \& MCINTYRE 109, 116-22, 225-61.

${ }^{40}$ See In the Matter of Dey, 9 N.J. Eq. 181 (Ch. 1852) (clear and unexceptionable); In re Guardianship of Mills, 250 Wis. 401, 27 N.W.2d 375 (1947) (clcar, convincing and satisfactory).

In a commitment proceeding, it has been held that the evidence must indicate incompetency beyond a reasonable doubt. In the Matter of Heukelekian, 24 N.J. Super. 407, 94 A.2d 501 (App. Div. 1953).

${ }^{50}$ Case No. 142, Court of Appeals of Preble County, Ohio, Oct. 31, 1962, p. 7. 
judge may have found outweighed, and the alleged incompetent is thereby denied the protection of meaningful appellate review. Such denial is even more striking where the appellate court refuses even to review a determination of incompetency if there is any evidence in the record to support the lower court's finding. ${ }^{51}$ Moreover, appellate courts do not seem to be highly critical under the rule that a preponderance of the evidence will support the lower court's finding. ${ }^{2}$

Apart from the question of evidentiary standards, danger has been seen in allocating determination of mental incompetency to a probate judge, and the requirement of jury trial has been considered an appropriate safeguard in proceedings where personal and property rights may be divested. ${ }^{53}$ However, it has been argued with equal vigor that since an incompetency proceeding is a technical inquiry there is no place for jury participation, and that a hearing conducted as informally as possible by a commission of experts would be the most effective means of determining an alleged incompetent's mental condition. ${ }^{54}$

If the adequacy of the safeguards to the alleged incompetent is questionable where his mental condition is determined in a formal court proceeding, it is difficult to conceive that the situation would be improved by dispensing with legal formalities. Moreover, while the courts should not close their eyes to modern medical knowledge nor attempt to act as their own medical experts, an incompetency proceeding is by no means purely a technical inquiry. The existence, cause and classification of mental disorders are matters pertinent to such proceedings upon which the psychiatrist should be consulted and heard. But the guardianship laws attach significance to mental disability only if it is sufficiently pronounced. The usual criterion of mental incompetency-inability to cope with ordinary or business affairs-indicates clearly that involuntary guardianship will not necessarily be imposed at the point where the psychiatrist

\footnotetext{
E1 See In the Matter of Estate of Reed, 198 Cal. 148, 243 Pac. 674 (1926).

52 E.g., Powers v. Chisman, 217 Ark. 508, 231 S.W.2d 598 (1950); Fish v. Poorman, 85 Kan. 237, 116 Pac. 898 (1911); Denver v. Beyer, 352 Pa. 386, 42 A.2d 747 (1945); Nagy Appeal, 169 Pa. Super. 388, 82 A.2d 591 (195I); Wade v. Sayre, 96 W. Va. 364, 123 S.E. 59 (1924).

v3 "It would be dangerous in the extreme to give courts of probate (which can have no jury), final jurisdiction of causes of such vast importance as it respects the liberty and happiness of our citizens." Shumway v. Shumway, 2 Vt. 339, 340 (1829).

" Gutrmacher \& Weihofen, Psychitatry and the Law 332-33 (1952).
} 
would discern mental illness ${ }^{55}$ or even where he would prescribe commitment to a mental institution. ${ }^{58}$ That the need for therapy bears no necessary relationship to legal incompetency is further demonstrated by statutes which require, in addition to serious mental disability, the involvement and danger of dissipation of property as conditions precedent to imposition of guardianship. .7

Since mental incompetency is determined by reference to a legal as opposed to a medical standard, there is no reason why a psychiatrist, rather than a court or jury, should be allowed to decide whether in a given case the standard has been satisfied. ${ }^{58}$ Perhaps the most desirable method of determining the need for guardianship would be a proceeding in which evidence presented by proponent and opponent could be considered by a jury along with the report of an independent medical commission. The prevalent tests of mental incompetency, phrased in terms of managerial ability, may be readily comprehended and applied by a jury of ordinary men. ${ }^{50}$ And a unanimous verdict, if required, might in itself provide strong assurance that the deprivation of rights incident to determination of mental incompetency has been fair and just.

\footnotetext{
${ }^{55}$ See In the Matter of Estate of Guilbert, 46 Cal. App. 55, 188 Pac. 807 (Dist. Ct. App. 1920); Grove v. Taylor, 143 Md. 184, 121 Atl. 923 (1923); In the Matter of Application of R.R., I40 N.J. Eq. 371, 54 A.2d 814 (Ch. 1947).

"See Davidson, Forenstc Psychiatry 196 (1952); Guttaincher \& Wejhofen, op. cit. supra note 54, at 339; LinDMAN \& McInTYRe 219 "'Incompetency and hospitalization are two distinct legal concepts determining scparate issues.").

${ }^{57}$ See, e.g., DeL. Code AnN. tit. 12, § 3914 (Supp. 1962); FLA. STAT. \$ 394.22 (1) (1961); Tenn. Code AnN. \$ 33-307 (1955); Lindman \& MaINTYRE 220.

ss See Leifer, supra note 22, at 567-72, 574-75. It is worthy of note that in Colorado, where a medical commission determines competency or incompetency, the aggrieved respondent may demand that the questions considered by the commission be tried by a jury. Colo. Rev. Star. AnN. \$ 71-1-11, -13 (Supp. 1960).

${ }^{59}$ It has been contended that inability to manage property, the typical test for mental incompetency in guardianship cases, can be proven "only by demonstrating mismanagement," Leifer, supra note 22, at 567, and therefore that psychiatric opinion in such cases is predicated upon evaluation not of medical data, but of "the same evidence presented ... by the other witnesses in the action." Faber v. Sweet Style Mfg. Corp., 40 Misc. 2d 212, 242 N.Y.S.2d 763, 768 (Sup. Ct. 1963). Moreover, "in the great majority of cases psychiatrists of equal qualification and experience will reach diametrically opposed conclusions on the same behavioral evidence." Ibid.
} 